OPEN ACCESS

Edited by:

Jayashri Kulkarni,

Monash University, Australia

Reviewed by:

Ugochinyere Vivian Ukah,

McGill University, Canada

Sidrah Nausheen,

Aga Khan University, Pakistan

*Correspondence:

Roopali Rajput

roopali.rajput@gmail.com

Jitender Sharma

jitendersharma.clinchem@gmail.com

tPresent address:

Roopali Rajput,

Department of Biochemistry, School of Chemical and Life Sciences, Jamia

Hamdard, New Delhi, India

Specialty section:

This article was submitted to

Maternal Health,

a section of the journal

Frontiers in Global Women's Health

Received: 30 December 2020

Accepted: 28 April 2021

Published: 24 June 2021

Citation:

Rajput $R$ and Sharma J (2021)

SARS-CoV-2 in Pregnancy: Fitting Into

the Existing Viral Repertoire.

Front. Glob. Womens Health

2:647836.

doi: 10.3389/fgwh.2021.647836

\section{SARS-CoV-2 in Pregnancy: Fitting Into the Existing Viral Repertoire}

\author{
Roopali Rajput ${ }^{1 *+}$ and Jitender Sharma ${ }^{2 *}$ \\ ${ }^{1}$ Independent Researcher, New Delhi, India, ${ }^{2}$ Department of Biochemistry, All India Institute of Medical Sciences, Bathinda, \\ India
}

The risk of viral infection during pregnancy is well-documented; however, the intervention modalities that in practice enable maternal-fetal protection are restricted by limited understanding. This becomes all the more challenging during pandemics. During many different epidemic and pandemic viral outbreaks, worse outcomes (fetal abnormalities, mortality, preterm labor, etc.) seem to affect pregnant women than what has been evident when compared to non-pregnant women. The condition of pregnancy, which is widely understood as "immunosuppressed," needs to be re-understood in terms of the way the immune system works during such a state. The immune system gets transformed to accommodate and facilitate fetal growth. The interference of such supportive conversion by viral infection and the risk of co-infection lead to adverse fetal outcomes. Hence, it is crucial to understand the risk and impact of potent viral infections likely to be encountered during pregnancy. In the present article, we review the effects imposed by previously established and recently emerging/re-emerging viral infections on maternal and fetal health. Such understanding is important in devising strategies for better preparedness and knowing the treatment options available to mitigate the relevant adverse outcomes.

\section{Keywords: pregnancy, SARS-CoV-2, maternal fetal health, COVID-19, vertical transmission, neonatal infection}

\section{INTRODUCTION}

Pregnancy leads to numerous physiological changes. Specifically, the immune system undergoes extensive transformation, often termed as becoming "immunocompromised," but it is nevertheless essential to support the growth of the developing fetus. However, this state is also one where the body is prone to various infections. Moreover, the probable transmission of virus infections from mother to fetus further complicates and aggravates the disease outcome. Such "vertical transmission" may be defined as the spread of any pathogen from a mother to her fetus (antepartum and intrapartum periods) or to a neonate (postpartum period) via the placenta in utero through contact with body fluid during delivery or via breastfeeding post-birth (1). It has been evident in several virus infections, such as HIV $(2,3)$, the Ebola virus (4), the Zika virus (5), etc. Until now, the only antenatal management for viral infections comprises the diagnosis of TORCH (toxoplasmosis, other, rubella, $\underline{\mathrm{CMV}}$, and $\underline{\mathrm{H} S V}$ type-1 and -2) infections. This panel is now expanded to include: syphilis, listeriosis, parvovirus, coxsackie virus, Trypanosoma cruzi, and others (6). However, no specific therapeutic or preventive approach is employed to address the adverse outcomes that may arise from such viral infections. The recent emergence of the potent novel SARS-CoV-2 has further contributed to this fear of vertical transmission and the unknown infection outcomes during pregnancy. The present review is focused on enumerating various viral infections prevalent during pregnancy and the associated risks to maternal and fetal health (Table 1) with special reference to the SARS-CoV-2 infection. 


\section{LONG-ESTABLISHED VIRAL INFECTIONS DURING PREGNANCY}

Over the years, the risk of viral pandemics has grown with evolving human activities. The first two trimesters of pregnancy exhibit increased inflammatory responses, but the third trimester is a phase of lower immunological activity $(36,37)$. Encountering any infectious pathogen makes things difficult for both the mother-to-be as well as the to-be-born baby. Progressing time demands a precise understanding of the viral diseases that may hold the potential for major outbreaks. The past pandemics caused by the influenza, Ebola, and Lassa viruses $(38,39)$ have shown pregnant women to be vulnerable targets with high incidences of fatality and disease severity $(40,41)$.

\section{Influenza Viruses}

Of the four (A, B, C, and D) types of influenza viruses, types $A$ and $B$ are known to cause mild to severe disease in humans. While, both A and B influenza viruses cause seasonal epidemics, pandemics are caused by only the influenza A viruses (IAVs) that are further classified into subtypes on the basis of two viral surface proteins, i.e., hemagglutinin (H) and neuraminidase (N) (42). At present, 18 different $\mathrm{H}$ subtypes (designated as $\mathrm{H} 1-\mathrm{H} 18)$ and 11 different N subtypes (designated as N1-N11) have been identified. Given these many subtypes of $\mathrm{H}$ and N, there can be a total of 198 combinations for possible influenza A virus variants, however, till now only 131 IAV subtypes have been identified (42). IAV (H1N1) and IAV (H3N2) are the most commonly circulating seasonal subtypes. Since the 2009 swine flu pandemic, the pH1N1 strain has undergone mutations and adapted itself as a seasonal IAV(H1N1) strain (42).

\section{Risk to the Mother}

Nevertheless, for pregnant women, the risk of severe illness or death from seasonal or pandemic strains of influenza viruses remains high (43). As evident during the 1918 and $1957 \mathrm{flu}$ pandemics, pregnant women exhibited high mortality rates (44, 45) and adverse pregnancy outcomes like spontaneous abortion and preterm birth $(44,46)$. More than $50 \%$ of influenza-infected pregnant women with pneumonia could not successfully carry the pregnancy to term (44) during the 1918 pandemic. On the other hand, the 1957 Asian flu witnessed birth defects, spontaneous abortions (47), fetal death, and preterm delivery (48). Seasonal influenza virus infections, monitored over 19 influenza seasons, exhibited a significantly higher likelihood of hospitalization of pregnant women with cardiopulmonary indications (49). Acute respiratory disease, asthma, or other underlying conditions further make pregnant women vulnerable to influenza viruses during the flu season $(50,51)$, and they are thus recommended for influenza vaccination.

\section{Risk to the Developing Fetus}

Although viremia is quite uncommon in influenza, it has been associated with severity of disease following infection with pH1N1/09 strain (52). Vertical transmission also seems to be a rare event (53); however, mouse model studies suggest possible adverse effects, as evident by histopathological alterations in the brain (54) or behavioral changes (55) in the progeny. Maternal influenza infection has also been linked to childhood leukemia (56), schizophrenia (57), and Parkinson disease (58). Overall, influenza viruses seem to project indirect effects on the developing fetus.

\section{Cytomegalovirus}

Cytomegalovirus is the major cause of infection during pregnancy, being responsible for infecting one in four pregnant women and $0.5-2 \%$ of all live birth infections (13). The incidence rate of CMV infection in women of a reproductive age belonging to developed and developing nations is 60 and $90 \%$, respectively (59). The development of anti-CMV antibodies in the mother is crucial in overcoming CMV infection; however, reactivation of the virus may occur in $10 \%$ of seropositive women. The highest occurrence rate of CMV may be attributed to the multiple pathways employed by the virus to gain entry into the host (60). The various cell types prone to CMV infection include epithelial cells, endothelial cells, muscle cells, fibroblasts, trophoblasts, and monocytes/macrophages, human neuronal cells (61). Although the disease severity is unaffected during pregnancy, CMV is known to impose serious implications during such states.

\section{Risk to the Mother}

Antepartum maternal infection remains mostly undetected due to non-specific symptoms and only mild febrile illness. Once the mother is infected, CMV may be transmitted to the fetus either through the placenta or via ingestion or aspiration of cervicovaginal secretions during delivery, breastfeeding, or rarely while ascending from the genital tract of the infected mother.

\section{Risk to the Developing Fetus}

The most common adverse fetal outcomes include congenital viral infection, which occurs in about $0.5 \%$ of cases (62). The primary viral targets include the ventricle, Organ of Corti, and neurons of the eighth cranial nerve, leading to congenital hearing loss (63). The rate of vertical transmission increases with progressing gestation with $36.5 \%$ during the first trimester, $40.1 \%$ during the second trimester, and $65 \%$ during the third trimester $(17,64)$, while, interestingly, the disease severity decreases with the increasing gestational age $(65,66)$. The infected neonates remain largely asymptomatic and start exhibiting neurodevelopmental damage within the first 3 years of age (67).

\section{Herpes Simplex Virus}

HSV-1 and HSV-2 have a combined seroprevalence of $72 \%$ in pregnant women (68). The most common STD is the genital herpes simplex virus (HSV-2) infection in adult females with an estimated $16 \%$ incidence in male and female combined and detection of almost 0.8 million new cases every year (21).

\section{Risk to the Mother}

As per the National Health and Nutrition Examination Surveys (NHANES), the incidence of HSV-2 infection is greater in women (23.1\%) than men (11.2\%) (40). Ethnicity, financial well-being, cocaine abuse, onset of sexual activity, sexual behavior and number of partners, and the presence of bacterial vaginosis all 
TABLE 1 | Various features of virus infections during pregnancy.

\begin{tabular}{|c|c|c|c|c|c|c|c|c|c|}
\hline Virus & $\begin{array}{l}\text { Year of } \\
\text { discovery }\end{array}$ & $\begin{array}{l}\text { Genome } \\
\text { characteristics }\end{array}$ & $\begin{array}{l}\text { Prevalence (year } \\
\text { of estimation) }\end{array}$ & Signs and symptoms & $\begin{array}{l}\text { Route of } \\
\text { transmission }\end{array}$ & $\begin{array}{l}\text { Risk of } \\
\text { vertical } \\
\text { transmission }\end{array}$ & $\begin{array}{l}\text { Mortality rate and } \\
\text { impact on infected } \\
\text { neonate }\end{array}$ & $\begin{array}{l}\text { Mortality rate and } \\
\text { impact on maternal } \\
\text { health }\end{array}$ & References \\
\hline $\begin{array}{l}\text { Influenza } \\
\text { viruses }\end{array}$ & $\begin{array}{l}\text { Influenza virus } \\
\text { first identified in } \\
1933 \text { by } \\
\text { Alphonse } \\
\text { Raymond } \\
\text { Dochez and } \\
\text { co-researchers }\end{array}$ & $\begin{array}{l}\text { Segmented -ve } \\
\text { sense ssRNA } \\
\text { genome; about } \\
13.5 \text { nucleotides }\end{array}$ & $\begin{array}{l}\text { 49.1\% IAV (2020); } \\
50.9 \% \text { IBV (2020) }\end{array}$ & $\begin{array}{l}\text { Signs: tachycardia, } \\
\text { facial flushing, clear } \\
\text { nasal discharge, and } \\
\text { cervical adenopathy. } \\
\text { Symptoms: Fever, } \\
\text { cough, malaise, rhinitis, } \\
\text { headache, sore throat, } \\
\text { myalgia, nausea, } \\
\text { vomiting, otitis, and } \\
\text { conjunctiva burning }\end{array}$ & $\begin{array}{l}\text { Respiratory } \\
\text { droplets/ aerosols } \\
\text { while coughing, } \\
\text { sneezing, or any } \\
\text { thrustful mouth } \\
\text { activities; contact } \\
\text { with nasal } \\
\text { secretions }\end{array}$ & High & $\begin{array}{l}0.15 \text { deaths per } \\
100,000 ; \\
\text { Indirect effects to fetus } \\
\text { include neurological } \\
\text { disorder, leukemia }\end{array}$ & $\begin{array}{l}\text { High mortality rate in } \\
\text { pregnancy; Adverse } \\
\text { outcomes include } \\
\text { pre-term birth, } \\
\text { spontaneous abortion; } \\
\text { complications increase } \\
\text { if co-occurrence of } \\
\text { pneumonia: more than } \\
50 \% \text { of pregnant } \\
\text { women with influenza } \\
\text { and pneumonia are } \\
\text { unable to carry the } \\
\text { pregnancy to full term }\end{array}$ & $(7-9)$ \\
\hline Cytomegaloviru & $\begin{array}{l}\text { sTypical signs } \\
\text { identified in } \\
1881 ; \\
\text { CMV isolation } \\
\text { and propagation } \\
\text { from humans } \\
\text { and mice in } \\
1956-1957 \text { by } \\
\text { Weller, Smith, } \\
\text { and Rowe }\end{array}$ & $\begin{array}{l}\text { Linear dsDNA; } \\
236 \text { kbp }\end{array}$ & $\begin{array}{l}\text { Ubiquitous } \\
\text { prevalence- About } \\
50 \% \text { till the age of } \\
40 \text { years; } 100 \% \text { in } \\
\text { Africa and Asia; } \\
80 \% \text { in Europe } \\
\text { and North America }\end{array}$ & $\begin{array}{l}\text { Mild illness with } \\
\text { non-specific } \\
\text { symptoms, such as } \\
\text { fever, sore throat, } \\
\text { fatigue, swollen glands; } \\
\text { and occasionally, } \\
\text { mononucleosis or } \\
\text { hepatitis }\end{array}$ & $\begin{array}{l}\text { Contact with } \\
\text { infected body } \\
\text { fluids, such as } \\
\text { saliva, urine, } \\
\text { blood, tears, } \\
\text { semen, and breast } \\
\text { milk }\end{array}$ & $\begin{array}{l}36-65 \% \text { from } \\
1 \text { st to last } \\
\text { trimester }\end{array}$ & $\begin{array}{l}\text { Rare; } \\
\text { Neurodevelopmental, } \\
\text { auditory } \\
\text { damage, microcephaly }\end{array}$ & $\begin{array}{l}1 \text { in every } 4 \text { pregnant } \\
\text { women is infected by } \\
\mathrm{CMV} ; 0.5-2 \% \text { of all live } \\
\text { birth infections }\end{array}$ & $(10-13)$ \\
\hline HSV-1 & $\begin{array}{l}\text { First HSV } \\
\text { isolation from } \\
\text { fever blister in } \\
1919 \text { by } \\
\text { Lowenstein }\end{array}$ & $\begin{array}{l}\text { Linear; dsDNA; } \\
152 \text { kbp }\end{array}$ & $12.1 \%(2016)$ & $\begin{array}{l}\text { Sores around the } \\
\text { mouth and lips }\end{array}$ & $\begin{array}{l}\text { Contact with } \\
\text { infected lesions, } \\
\text { mucosal surface, } \\
\text { or via genital or } \\
\text { oral secretions }\end{array}$ & $\begin{array}{l}\text { Medium } \\
\text { during late } \\
\text { pregnancy; } \\
\text { Low during } \\
\text { early pregnancy }\end{array}$ & $\begin{array}{l}80 \% \text {; } \\
\text { Localized skin, eye, } \\
\text { and mouth (SEM), } \\
\text { central nervous system } \\
\text { (CNS) with or without } \\
\text { SEM or disseminated } \\
\text { disease; major impact: } \\
\text { blindness, seizures, } \\
\text { and learning disabilities }\end{array}$ & $\begin{array}{l}\text { Spontaneous abortion, } \\
\text { intrauterine growth } \\
\text { restriction, preterm } \\
\text { labor, and congenital } \\
\text { and neonatal herpes } \\
\text { infections }\end{array}$ & $(14-18)$ \\
\hline HSV-2 & & $\begin{array}{l}\text { Linear; dsDNA; } \\
\text { linear; } 154.7 \mathrm{kbp}\end{array}$ & $48.1 \%(2016)$ & $\begin{array}{l}\text { Sores around genitals } \\
\text { or rectum }\end{array}$ & & & & & \\
\hline $\begin{array}{l}\text { Varicella } \\
\text { zoster virus }\end{array}$ & $\begin{array}{l}\text { First isolated in } \\
1954 \text { by Thomas } \\
\text { Huckle Weller }\end{array}$ & $\begin{array}{l}\text { Linear dsDNA; } \\
125 \mathrm{~kb}\end{array}$ & $\begin{array}{l}97 \% \text { decline in } \\
\text { VSV infections } \\
\text { since pre-vaccine } \\
\text { era from } \\
1993-1995 \text { to } \\
2013-2014 \text { in the } \\
\text { U.S. }\end{array}$ & $\begin{array}{l}\text { In children, rash on } \\
\text { scalp, face, and trunk } \\
\text { are the first signs, } \\
\text { followed by rash on } \\
\text { extremities, fever, } \\
\text { malaise, headache. In } \\
\text { adults, fever and } \\
\text { malaise for initial } 2 \text { days } \\
\text { of infection followed by } \\
\text { appearance of rash }\end{array}$ & $\begin{array}{l}\text { Contact with } \\
\text { infected lesion } \\
\text { fluid; } \\
\text { person-to-person }\end{array}$ & $\begin{array}{l}\text { High in 8-20 } \\
\text { weeks of } \\
\text { gestation }\end{array}$ & $\begin{array}{l}30 \% \text {; congenital } \\
\text { varicella syndrome }\end{array}$ & $\begin{array}{l}10-20 \% \text { VSV infections } \\
\text { during pregnancy are } \\
\text { accompanied by } \\
\text { pneumonia, which may } \\
\text { cause up to } 40 \% \\
\text { mortality }\end{array}$ & $(19-21)$ \\
\hline
\end{tabular}


TABLE 1 | Continued

\begin{tabular}{|c|c|c|c|c|c|c|c|c|c|}
\hline Virus & $\begin{array}{l}\text { Year of } \\
\text { discovery }\end{array}$ & $\begin{array}{l}\text { Genome } \\
\text { characteristics }\end{array}$ & $\begin{array}{l}\text { Prevalence (year } \\
\text { of estimation) }\end{array}$ & Signs and symptoms & $\begin{array}{l}\text { Route of } \\
\text { transmission }\end{array}$ & $\begin{array}{l}\text { Risk of } \\
\text { vertical } \\
\text { transmission }\end{array}$ & $\begin{array}{l}\text { Mortality rate and } \\
\text { impact on infected } \\
\text { neonate }\end{array}$ & $\begin{array}{l}\text { Mortality rate and } \\
\text { impact on maternal } \\
\text { health }\end{array}$ & References \\
\hline $\begin{array}{l}\text { Hepatitis C } \\
\text { virus }\end{array}$ & $\begin{array}{l}1987 \text { by Michael } \\
\text { Houghton, } \\
\text { Qui-Lim Choo, } \\
\text { George Kuo, } \\
\text { and Daniel W. } \\
\text { Bradley; } 1988 \text { by } \\
\text { Harvey J. Alter } \\
\text { and his team }\end{array}$ & $\begin{array}{l}\text { ssRNA; } \\
\text { positive-sense; } \\
9600 \text { nucleotides } \\
\text { long }\end{array}$ & $\begin{array}{l}1 \% \text { viraemic } \\
\text { prevalence } \\
\text { accounting for } \\
71.1 \text { million cases } \\
\text { (2015) with } \\
\text { genotypes } 1 \text { and } 3 \\
\text { being the most } \\
\text { common; } \\
2.8 \% \\
\text { (sero-prevalence } \\
\text { as per systematic } \\
\text { review, 2013) }\end{array}$ & $\begin{array}{l}\text { Acute hepatitis C } \\
\text { usually shows no } \\
\text { signs/symptoms, but } \\
\text { may exhibit: jaundice, } \\
\text { along with fatigue, } \\
\text { nausea, fever, and } \\
\text { muscle ache; } \\
\text { Chronic hepatitis C is } \\
\text { generally a silent } \\
\text { infection not causing } \\
\text { any disease until the } \\
\text { liver gets substantially } \\
\text { damaged and leads to } \\
\text { easy bleeding and } \\
\text { bruising, fatigue, poor } \\
\text { appetite, jaundice, } \\
\text { dark-color urine, itchy } \\
\text { skin, ascites, swelling in } \\
\text { legs, weight loss, } \\
\text { confusion, drowsiness } \\
\text { and slurred speech } \\
\text { (hepatic } \\
\text { encephalopathy), } \\
\text { spider-like appearance } \\
\text { of blood vessels on } \\
\text { skin (spider angiomas) }\end{array}$ & Infected blood & $\begin{array}{l}5.8 \% \text {; } \\
\text { With higher } \\
\text { risk in case of } \\
\text { co-infection } \\
\text { with } \\
\text { HIV (10.8\%) }\end{array}$ & $\begin{array}{l}\text { Preterm birth, late } \\
\text { neonatal death }\end{array}$ & $\begin{array}{l}\text { Intrahepatic cholestasis } \\
\text { pregnancy }\end{array}$ & $\begin{array}{l}{[(22,23), \text { https:// }} \\
\text { www.mayoclinic. } \\
\text { org/diseases- } \\
\text { conditions/ } \\
\text { hepatitis-c/ } \\
\text { symptoms- } \\
\text { causes/syc- } \\
20354278]\end{array}$ \\
\hline $\begin{array}{l}\text { Hepatitis E } \\
\text { virus }\end{array}$ & 1978 & $\begin{array}{l}\text { ssRNA, } \\
\text { positive-sense; } \\
7.2 \mathrm{~kb}\end{array}$ & $\begin{array}{l}\text { About } 20 \text { million } \\
\text { cases including } \\
3.3 \text { million } \\
\text { symptomatic } \\
\text { infections per year; } \\
3.3 \% \text { mortality } \\
\text { estimate (2015) }\end{array}$ & $\begin{array}{l}\text { Acute hepatitis E } \\
\text { shows no } \\
\text { signs/symptoms; } \\
\text { Chronic disease } \\
\text { exhibits: fever, fatigue, } \\
\text { loss of appetite, } \\
\text { nausea, vomiting, } \\
\text { abdominal pain, } \\
\text { jaundice, dark color } \\
\text { urine, clay-color stool, } \\
\text { pain in the joints }\end{array}$ & Fecal-oral route & $\begin{array}{l}\text { High during } \\
\text { the second } \\
\text { and third } \\
\text { trimester }\end{array}$ & $\begin{array}{l}\text { High perinatal morbidity } \\
\text { and mortality }\end{array}$ & $\begin{array}{l}20-25 \% \text { mortality in } \\
\text { pregnancy during the } \\
\text { third trimester; } \\
\text { Fulminant hepatitis, } \\
\text { acute liver failure, death }\end{array}$ & $\begin{array}{l}\text { [(24), https://www. } \\
\text { cdc.gov/hepatitis/ } \\
\text { hev/hevfaq.htm; } \\
\text { https://www.who. } \\
\text { int/news-room/ } \\
\text { fact-sheets/detail/ } \\
\text { hepatitis-e\#:Isim: } \\
\text { text=Hepatitis } \\
\text { \%20E\%20is\%20a } \\
\text { \%20liver, of } \\
\text { \%20hepatitis } \\
\text { \%20E\%20(1)] }\end{array}$ \\
\hline
\end{tabular}


TABLE 1 | Continued

\begin{tabular}{|c|c|c|c|c|c|c|c|c|c|}
\hline Virus & $\begin{array}{l}\text { Year of } \\
\text { discovery }\end{array}$ & $\begin{array}{l}\text { Genome } \\
\text { characteristics }\end{array}$ & $\begin{array}{l}\text { Prevalence (year } \\
\text { of estimation) }\end{array}$ & Signs and symptoms & $\begin{array}{l}\text { Route of } \\
\text { transmission }\end{array}$ & $\begin{array}{l}\text { Risk of } \\
\text { vertical } \\
\text { transmission }\end{array}$ & $\begin{array}{l}\text { Mortality rate and } \\
\text { impact on infected } \\
\text { neonate }\end{array}$ & $\begin{array}{l}\text { Mortality rate and } \\
\text { impact on maternal } \\
\text { health }\end{array}$ & References \\
\hline HIV & $\begin{array}{l}\text { First isolated and } \\
\text { identified by Luc } \\
\text { Montagnier's } \\
\text { team (Luc } \\
\text { Montagnier and } \\
\text { Françoise } \\
\text { Barré-Sinoussi } \\
\text { received the } \\
\text { Nobel Prize in } \\
\text { 2008) }\end{array}$ & $\begin{array}{l}\text { two copies of +ve } \\
\text { sense ssRNA; } \\
\text { 9,200-9,800 } \\
\text { nucleotides }\end{array}$ & $\begin{array}{l}0.8 \% \text { in adults } \\
\text { (2018); } 75.7 \text { million } \\
\text { diagnosed HIV+ } \\
\text { since } 1981 ; 21 \% \\
\text { unaware of their } \\
\text { HIV status }\end{array}$ & $\begin{array}{l}\text { Non-specific } \\
\text { symptoms, such as } \\
\text { fever, lymph node } \\
\text { enlargement, fatigue, } \\
\text { malaise, rash with } \\
\text { small, only slightly } \\
\text { raised lesions, and/or } \\
\text { gastrointestinal } \\
\text { symptoms }\end{array}$ & $\begin{array}{l}\text { Blood or } \\
\text { transplanted } \\
\text { organs, including } \\
\text { bone, vertical } \\
\text { transmission, } \\
\text { breast milk }\end{array}$ & $\begin{array}{l}>90 \% \text { in late } \\
\text { pregnancy }\end{array}$ & $\begin{array}{l}\text { 0.04-0.094\%; } \\
\text { If left untreated- } \\
\text { Repeated fungal mouth } \\
\text { infections (thrush); Poor } \\
\text { weight gain; Enlarged } \\
\text { lymph nodes; } \\
\text { Neurological problems; } \\
\text { Multiple bacterial } \\
\text { infections } \\
\text { (i.e., pneumonia) }\end{array}$ & & (25-29) \\
\hline Lassa virus & 1969 & $\begin{array}{l}\text { Two ssRNA } \\
\text { segments; } 10.4 \mathrm{~kb} \\
\text { combined length } \\
\text { (short strand: } \\
3.4 \mathrm{~kb} \text {; long strand } \\
7 \mathrm{~kb} \text { ) }\end{array}$ & $\begin{array}{l}0.1 \text { million- } 0.3 \\
\text { million cases per } \\
\text { year including } \\
\text { about } 5,000 \\
\text { deaths per year in } \\
\text { the west of Africa }\end{array}$ & $\begin{array}{l}\text { Mild in } 80 \% \text { cases: } \\
\text { fever, malaise, } \\
\text { weakness, and } \\
\text { headache; } \\
\text { Serious in rest of the } \\
20 \% \text { cases: } \\
\text { hemorrhage in gums, } \\
\text { eyes, or nose, etc., } \\
\text { respiratory distress, } \\
\text { frequent vomiting, facial } \\
\text { swelling, chest- back- } \\
\text { and abdomen- pain, } \\
\text { shock, neurological } \\
\text { symptoms, like, loss of } \\
\text { hearing, tremors, and } \\
\text { encephalitis. } \\
\text { Multi-organ failure in } \\
\text { more severe cases } \\
\text { leading to death }\end{array}$ & $\begin{array}{l}\text { Zoonotic } \\
\text { transmission: via } \\
\text { excretions of } \\
\text { infected rodent } \\
\text { multi-mammate } \\
\text { rat, Mastomys } \\
\text { natalensis; } \\
\text { Human-human } \\
\text { transmission via } \\
\text { contact with body } \\
\text { fluids of the } \\
\text { infected person }\end{array}$ & $\begin{array}{l}\text { High risk due } \\
\text { to high viral } \\
\text { load in the } \\
\text { placenta and } \\
\text { maternal } \\
\text { blood }\end{array}$ & $\begin{array}{l}\text { Premature birth } \\
\text { Note:-More evidence } \\
\text { with well-planned } \\
\text { studies is required, } \\
\text { although the risk is high } \\
\text { due to serious } \\
\text { outcomes of infection } \\
\text { and high viral load in } \\
\text { infected maternal and } \\
\text { fetal tissues }\end{array}$ & $\begin{array}{l}\text { high viral load in the } \\
\text { placenta, fetal tissue, } \\
\text { and maternal blood } \\
\text { impose adverse } \\
\text { outcomes }\end{array}$ & $\begin{array}{l}\text { https://www.cdc. } \\
\text { gov/vhf/lassa/pdf/ } \\
\text { factsheet.pdf }\end{array}$ \\
\hline Zika virus & 1947 & $\begin{array}{l}\text { Positive sense; } \\
\text { ssRNA; about } \\
11 \mathrm{~kb}\end{array}$ & $\begin{array}{l}27 \% \text { confirmed } \\
\text { cases out of } 0.7 \\
\text { million suspected } \\
\text { cases in America } \\
(2015-2017)\end{array}$ & $\begin{array}{l}\text { Mostly asymptomatic; } \\
\text { otherwise mild clinical } \\
\text { features that are typical } \\
\text { of maculopapular rash, } \\
\text { like, fever, arthralgia, } \\
\text { non-purulent } \\
\text { conjunctivitis }\end{array}$ & $\begin{array}{l}\text { Through infected } \\
\text { Ae. aegypti and } \\
\text { Ae. Albopictus } \\
\text { vectors }\end{array}$ & $\begin{array}{l}47,28 \text {, and } \\
25 \% \text { in first, } \\
\text { second, and } \\
\text { third } \\
\text { trimesters, } \\
\text { respectively }\end{array}$ & $\begin{array}{l}\text { Congenital } \\
\text { microcephaly, serious } \\
\text { brain anomalies, } \\
\text { Guillain-Barré } \\
\text { syndrome, rare cases } \\
\text { of encephalopathy, } \\
\text { meningoencephalitis, } \\
\text { myelitis, uveitis, } \\
\text { paresthesia, and severe } \\
\text { thrombocytopenia }\end{array}$ & $\begin{array}{l}\text { Fetal loss, IUGR } \\
\text { pregnancies }\end{array}$ & (30-32) \\
\hline
\end{tabular}


TABLE 1 | Continued

\begin{tabular}{|c|c|c|c|c|c|c|c|c|c|}
\hline Virus & $\begin{array}{l}\text { Year of } \\
\text { discovery }\end{array}$ & $\begin{array}{l}\text { Genome } \\
\text { characteristics }\end{array}$ & $\begin{array}{l}\text { Prevalence (year } \\
\text { of estimation) }\end{array}$ & Signs and symptoms & $\begin{array}{l}\text { Route of } \\
\text { transmission }\end{array}$ & $\begin{array}{l}\text { Risk of } \\
\text { vertical } \\
\text { transmission }\end{array}$ & $\begin{array}{l}\text { Mortality rate and } \\
\text { impact on infected } \\
\text { neonate }\end{array}$ & $\begin{array}{l}\text { Mortality rate and } \\
\text { impact on maternal } \\
\text { health }\end{array}$ & References \\
\hline Ebola virus & 1976 & $\begin{array}{l}\text { Non-segmented; } \\
\text { negative sense } \\
\text { RNA; 18-19 kb }\end{array}$ & $\begin{array}{l}28,000 \text { confirmed } \\
\text { cases and 11,000 } \\
\text { deaths } \\
\text { (2013-2016); case } \\
\text { fatality rate } \\
25-90 \% \text { (average } \\
\text { nearly 50\%) as per } \\
\text { previous } \\
\text { outbreaks }\end{array}$ & $\begin{array}{l}\text { Sudden symptoms: } \\
\text { include fever, fatigue, } \\
\text { muscle pain, } \\
\text { headache, and sore } \\
\text { throat; } \\
\text { Other symptoms: } \\
\text { vomiting, diarrhea, } \\
\text { rash, impaired kidney } \\
\text { and liver function, } \\
\text { internal and external } \\
\text { bleeding, like, } \\
\text { gum-bleeding or blood } \\
\text { excretion in stool }\end{array}$ & $\begin{array}{l}\text { Zoonotic } \\
\text { transmission: via } \\
\text { contact of blood, } \\
\text { body } \\
\text { fluids/secretions, } \\
\text { tissues, etc. of } \\
\text { infected fruit bats, } \\
\text { chimpanzees, } \\
\text { gorillas, monkeys, } \\
\text { forest antelope, or } \\
\text { porcupines; } \\
\text { Human-human } \\
\text { transmission: } \\
\text { direct contact via } \\
\text { broken skin tissue } \\
\text { or } \\
\text { mucous membranes }\end{array}$ & $\begin{array}{l}\text { Pregnant } \\
\text { women } \\
\text { recovered } \\
\text { from acute } \\
\text { Ebola may } \\
\text { express virus } \\
\text { in breastmilk, } \\
\text { or in } \\
\text { pregnancy- } \\
\text { related } \\
\text { body-fluids } \\
\text { and tissues, } \\
\text { which exhibits } \\
\text { a high risk of } \\
\text { transmission } \\
\text { to baby and } \\
\text { to others. }\end{array}$ & $\begin{array}{l}\text { Preterm labor and } \\
\text { spontaneous abortion }\end{array}$ & $\begin{array}{l}\text { Vaginal and uterine } \\
\text { bleeding causing } \\
\text { maternal death }\end{array}$ & $\begin{array}{l}\text { [(33), https://www. } \\
\text { who.int/news- } \\
\text { room/fact-sheets/ } \\
\text { detail/ebola-virus- } \\
\text { disease] }\end{array}$ \\
\hline SARS-CoV-2 & $\begin{array}{l}\text { Identified in } \\
2020 \text { by the } \\
\text { China Novel } \\
\text { Coronavirus } \\
\text { Investigating and } \\
\text { Research Team } \\
\text { and named by } \\
\text { the } \\
\text { Coronaviridae } \\
\text { Study Group of } \\
\text { the International } \\
\text { Committee on } \\
\text { Taxonomy of } \\
\text { Viruses in the } \\
\text { same year }\end{array}$ & $\begin{array}{l}\text { +ve sense ssRNA; } \\
29,811 \\
\text { nucleotides }\end{array}$ & $\begin{array}{l}79.2 \text { million cases } \\
\text { and over } 1.7 \\
\text { million deaths } \\
\text { since onset of the } \\
\text { pandemic in } 2019\end{array}$ & $\begin{array}{l}\text { Major: fever, dry } \\
\text { cough, tiredness; } \\
\text { Minor: aches and } \\
\text { pains, sore throat, } \\
\text { diarrhea, conjunctivitis, } \\
\text { headache, loss of taste } \\
\text { or smell, a rash on the } \\
\text { skin, or discoloration of } \\
\text { fingers or toes } \\
\text { Occasional serious } \\
\text { symptoms: difficulty } \\
\text { breathing or shortness } \\
\text { of breath, chest pain or } \\
\text { pressure, loss of } \\
\text { speech or movement }\end{array}$ & $\begin{array}{l}\text { Respiratory } \\
\text { droplets/aerosols; } \\
\text { fomites }\end{array}$ & $\begin{array}{l}\text { 2-3.9\%; } \\
\text { however true } \\
\text { estimate yet } \\
\text { known }\end{array}$ & $\begin{array}{l}\text { True estimate not } \\
\text { known yet; preterm } \\
\text { labor and delivery, } \\
\text { premature rupture of } \\
\text { membranes, low birth } \\
\text { weight, intrauterine } \\
\text { fetal distress and } \\
\text { growth restraint, } \\
\text { feeding intolerance, } \\
\text { asphyxia, pneumonia, } \\
\text { and respiratory distress }\end{array}$ & $\begin{array}{l}\text { Preterm labor and } \\
\text { delivery, premature } \\
\text { rupture of membranes }\end{array}$ & $(1,34,35)$ \\
\hline
\end{tabular}


seem to affect women's vulnerability to HSV before pregnancy (69). HSV infection during pregnancy causes spontaneous abortion, intrauterine growth restriction, preterm labor, and congenital and neonatal herpes infections (70).

\section{Risk to the Developing Fetus}

The development of anti-HSV antibodies seems to have no effect on neonates. However, the risk of neonatal herpes infection increases with the gestational period from $<1 \%$ during early pregnancy to up to $50 \%$ during late pregnancy $(21,71)$. The reason for this may be the inability of antibody development before labor to enable inhibition of HSV replication and shedding. Transplacental vertical transmission is rare, and $80-$ $90 \%$ of perinatal transmission happens during delivery (17). HSV infection in neonates may affect localized skin, eye, and mouth (SEM) and the central nervous system (CNS) with or without SEM or disseminated disease. The untreated latter cases exhibit high (80\%) mortality (14-17). The major neurological defects in infected neonates include blindness, seizures, and learning disabilities.

\section{Varicella Zoster Virus}

VSV infection causes chickenpox, which is a common but highly contagious illness primarily experienced during childhood. The major delinquent manifestation is the development of maculopapular to vesicular rashes all over the body. The virus gets transmitted through aerosols and close contact (72). An initial varicella zoster infection following chickenpox may lead to the latent stay of the virus in dorsal root ganglia for years and may reactivate as herpes zoster during adulthood. Although VSV infection occurs during childhood and most women of reproductive age have developed considerable immunity against it, it may still occur in $0.7 / 1,000$ pregnancies.

\section{Risk to the Mother and the Developing Fetus}

Primary VSV infection in pregnant women causes considerable maternal and fetal morbidity and mortality. Although the pediatric infection is self-limiting, $10-20 \%$ of VSV infections in pregnancy are accompanied by pneumonia, a condition that may lead to up to $40 \%$ fatality (21). Fetal morbidity and mortality are linked to the development of congenital varicella syndrome, which may occur in $0.4-2 \%$ VSV-confirmed pregnancies within the initial 20 weeks of gestation (73). The syndrome is characterized by limb hypoplasia, microcephaly, hydrocephaly, cataracts, intrauterine growth restriction, and mental retardation (74) and is believed to be caused due to in utero VSV reactivation instead of primary fetal infection (75).

\section{Hepatitis C Virus \\ Risk to the Mother}

$\mathrm{HCV}$ poses a severe threat to pregnant women with adverse fetal outcomes, such as preterm birth (76), late neonatal death (77), and intrahepatic cholestasis of pregnancy (the risk of which increases if the mother has been HCV positive before pregnancy) (78). Much of the disease burden data come from the United States, where the elevated incidence of HCV aligned with the opioid epidemic. The HCV burden increased in IDUassociated HCV cases in the younger population, consisting of women who were pregnant and of reproductive age (79). There are geographical inequities in HCV healthcare management, and the prevalence thus varies across the globe. The incidence of $\mathrm{HCV}$ cases elevated from 1.8 to 4.7 per 1,000 live births according to a recent analysis of the National Center for Health Statistics data (80). As per the CDC, the rate of $\mathrm{HCV}$ infection increased by over $400 \%$ ( 0.8 to 4.1 per 1,000$)$ in cases of women where live births were recorded. In pregnant women belonging to the European Union/European Economic Area, the HCV incidence is $0.1-0.9 \%$ (81) while that of Africa is $3.4 \%$ (82).

\section{Risk to the Developing Fetus}

Vertical transmission of $\mathrm{HCV}$ is estimated at 5.8\% with a significantly higher rate among HIV-co-infected (10.8\%) pregnancies (83). In the US, the incidence is 3.6\% (84), whereas in Spain it is 7\% (85) in HCV/HIV co-infected pregnant women. In spite of these statistics, the true estimate is still a challenge owing to the availability of scarce information on the subject and also the substantial time gap between childbirth and testing for HCV antibodies (currently recommended at $\geq 18$ months of age), which may lead to loss of contact with the cases to be examined (79). The mode of delivery or breastfeeding does not appear to impact the risk of HCV transmission, while the prolonged duration of ruptured membranes may be a risk factor for the same (86). The association between the viral load and vertical transmission of $\mathrm{HCV}$ is under speculation, but conclusive recommendations cannot be made due to insufficient data (79).

\section{Hepatitis E Virus}

Hepatitis E Virus is the major cause of self-limiting acute viral hepatitis in healthy adults and chronic viral hepatitis in immunocompromised individuals.

\section{Risk to the Mother}

There have been several investigations to understand the effects of HEV infection on maternal and fetal health; however, definitive conclusions cannot be made due to contradictory observations among the different studies (87-90). In a recent 5years single-center study in India, 1,088 patients (550 pregnant and 538 non-pregnant controls) were evaluated to understand the course and severity of HEV infection during pregnancy (91). All the patients were confirmed for either acute viral hepatitis $(\mathrm{AVH})$ or acute liver failure (ALF) through clinical examination and biochemical investigations. The HEV infection was observed in $80.36 \%$ of pregnant women, with $73.38 \%$ prevalence in ALF cases alone. Also, the mortality rate was recorded at almost $76 \%$ due to HEV-infection in the studied subjects (91). Other studies suggest fulminant hepatitis failure with a mortality rate of up to $30 \%$ in pregnant women due to HEV infection $(88,90,92)$.

\section{Risk to the Developing Fetus}

Vertical transmission of HEV with significant perinatal morbidity and mortality has been reported $(90,93,94)$, and ribavirin and IFN- $\alpha$ administration is thus not carried out during pregnancy due to the risk of birth defects $(42,95,96)$. 
The adverse fetal outcomes include preterm labor $(97,98)$ and disseminated intravascular coagulation (DIC) (93).

\section{Human Immunodeficiency Virus/Acquired Immunodeficiency Syndrome}

HIV/AIDS continues to be the worst pandemic ever with 75.7 million individuals diagnosed with HIV infection and about 32.7 million deaths between 1981 and up until the end of 2019 (99). Globally, in 2019, women represented almost $48 \%$ of the total new HIV cases, and, likewise, in 2018, the incidence of new HIV cases in women aged $15-24$ years was $55 \%$ higher as compared to men of the same age range. While the majority of adult women contract HIV infection via heterosexual contact, most childhood infections are caused due to vertical transmission (100). Almost $90 \%$ of untreated HIV cases proceed to develop AIDS and subsequent death with opportunistic infections due to the significant reduction in $\mathrm{CD} 4 \mathrm{~T}$ cells. However, with significant improvements in medical care management of HIV cases, the life expectancy can be increased by as long as 15 years through the administration of anti-retroviral therapy.

\section{Risk to the Mother and the Developing Fetus}

Vertical transmission accounted for about 180,000 global new HIV infections in 2017 (100). Fortunately, with advanced healthcare systems and the use of cART, rates of perinatal transmission have reduced, leading to a smaller number of childhood exposures progressing into full-blown AIDS. Although the development of illness following HIV infection is not affected by the pregnant state, the risk of mother-to-child transmission forms a major concern. Vertical transmission of HIV can occur during intrauterine life, delivery, or breastfeeding. The adverse fetal outcomes include preterm birth, low birth weight, small size for gestational age, and stillbirth (101).

\section{Lassa Virus}

The Lassa virus causes Lassa fever, or Lassa hemorrhagic fever (LHF), an acute viral hemorrhagic fever that was first identified in 1969 in Lassa, Nigeria (96) and is transmitted through "multimammate rat" (Mastomys natalensis).

\section{Risk to the Mother}

The illness is endemic and a major cause of mortality for pregnant women in the West African regions, viz., Sierra Leone, Liberia, Guinea, and Nigeria (102). Fascinatingly, in cases of Lassa virus infection, maternal health rapidly improves as soon as the fetus is removed from the uterus either by spontaneous abortion or delivery (38). Also, the mortality is higher in cases of nonevacuated uterus (10/26 fatal outcomes) as compared to the cases where delivery was ensured (4/39 fatalities) (38). This may be due to placenta-mediated regulation of the maternal immune system. Even if the placenta is not directly infected, it is capable of responding to invading pathogens and hence seems to be a crucial regulator of a pregnant woman's response to virus infection (103). High viral load in maternal blood, placenta, and fetal tissue accounts for higher mortality rates of pregnant women than the non-pregnant counterparts (104). Maternal mortality risk increases with the progressing gestational period: from $7 \%$ during the first two trimesters to as high as $30 \%$ in the last trimester. Almost 50\% mortality has been recorded within a month postpartum in contrast to $13 \%$ in non-pregnant females (104).

\section{Risk to the Developing Fetus}

Lassa virus infection is speculated to impose adverse outcomes to the developing fetus, given the high viral load in placenta, fetal tissue, and maternal blood. However, due to extremely limited evidence on clinical characteristics and course of Lassa fever in pregnancy and variability in study design and methodologies employed, the exact maternal and perinatal outcomes cannot be convincingly described (105). The vertical transmission and premature birth have been reported, though.

\section{RE-EMERGING AND LESS UNDERSTOOD VIRAL THREATS}

\section{Zika Virus}

The unexpected re-emergence of the Zika virus in 2015 and the subsequent outbreak in Brazil reinforced that the management of viral infections is of utmost significance during pregnancy.

\section{Risk to the Mother and the Developing Fetus}

Zika virus is transmitted by mosquitoes and potentially via a sexual route (106).

What was previously known to progress from fever and rash to Guillain-Barre syndrome is now reported to cause fetal brain and CNS anomalies in neonates born to Zika-virusinfected women $(95,107)$, as confirmed by the presence of viral nucleic acid in amniotic fluid (108). The adverse fetal outcomes include microcephaly, abortions and IUGR pregnancies, and other complications. Viral load in amniotic epithelia during midgestation is reported to be higher than in the late-gestation period (109). Cytotrophoblasts were also observed as viral targets, and, during early gestation, they were linked to loss of proliferation. Such a condition may explain the miscarriage and growth restriction outcomes.

\section{Ebola Virus}

Ebola virus, the cause of Ebola Hemorrhagic fever (EHF), primarily causes human infections in Africa (110). However, with extensive global travel, infectious nature of the pathogen, and potential effects on maternal and fetal health the virus has become a global threat. Although quite uncommon, the Ebola virus has imposed severe illness and considerable EHF outbreaks in Africa. The causative species, Zaire ebolavirus, was identified in 1976 in Kikwit and, during the then epidemic incidence of Ebola virus infection, saw a higher incidence among women than men $(111,112)$. Also, mortality was higher in pregnant than non-pregnant women. The 1976 Ebola epidemic witnessed $46 \%$ infections and $89 \%$ mortality among pregnant women.

\section{Risk to the Mother}

One of the main manifestations during the 1976 epidemic was vaginal and uterine bleeding leading to the death of infected 
pregnant females (93\% mortality rate) within 10 days of onset of symptoms $(113,114)$.

\section{Risk to the Developing Fetus}

The adverse fetal outcomes of EHF during pregnancy include preterm birth and abortion. The 1976 epidemic led to a $23 \%$ incidence of spontaneous abortions of pregnancies, while the same was considerably higher (67\%) in the 1995 epidemic (113, 114).

\section{SARS-CoV-2}

Adverse outcomes of pregnancy have been reported following infection with the previous SARS- and MERS- coronaviruses (15, 51,86 ); hence the current pandemic SARS-CoV-2 aggravates the apprehension related to maternal and fetal well-being. Initially, there have been fears associated with SARS-CoV-2 led pregnancy complications and adverse fetal outcomes $(26,28,115,116)$. Further studies with large sample sizes (116 in China and 427 in the UK) ruled out such apprehensions, however, and demonstrated a higher rate of cesarian section deliveries $(4,104$, $117,118)$.

\section{Risk to the Mother}

Few studies suggest mild illness in COVID-19 confirmed pregnant females with lower mortality than the non-pregnant COVID-19 patients (119) and premature delivery as a major adverse fetal outcome (119). As per a month's rigorous surveillance in Sweden, a requirement of intensive care for COVID-19 confirmed pregnant and early postpartum women has been reported (120) at a relative risk of 5.4 (95\% CI, 2.8910.08 ). The patients also required invasive mechanical ventilation with a relative risk of 4.0 (95\% CI 1.75-9.14) in contrast to the non-pregnant women of similar age. An expansion of the denominator to include 50\% more pregnancies (possible miscarriages and early intrauterine fatalities), still exhibited a high RR 3.5 (95\% CI, 1.86-6.52). These findings, although are from only 53 patients aged between 20 and 45 years without any information on co-morbidities, reflect the need to focus and further study the possible risks associated with SARS-CoV2 infection in pregnant women (120). Another recent study aimed at investigating the outcomes of pregnancy and analysis of the clinical features in COVID-19 confirmed pregnancies vs. non-pregnant cases highlighted the worsening of morbidity with the progression of pregnancy due to SARS-CoV-2 infection. The mortality rate seemed to be unaffected in this retrospective analysis. The study analyzed the record of 188 pregnant cases and 799 age-matched non-pregnant counterparts from four tertiary care hospitals in Turkey. The severity of SARS-CoV-2 infection was significantly high in pregnant women especially at $>20$ weeks of gestation $(p<0.001)$. In comparison to non-pregnant cases, pregnant cases displayed significantly high frequency of oxygen support (10.1 vs. $4.8 \% ; p \leq 0.001$ ), intensive care unit admission (3.2 vs. $0.6 \% ; p=0.009)$, presence of fever (12.8 vs. $4.4 \%$; $p<$ 0.001 ), tachypnea ( 7.0 vs. $2.4 \% ; p=0.003$ ), and tachycardia ( 16.0 vs. $1.9 \%$; $p<0.001)$. Co-morbidities were present in $14.4 \%$ of pregnant women. Of the 188 pregnant cases, about $32 \%$ delivered (18.3\% vaginal and $81.7 \%$ cesarean) during the SARS-CoV-2 infected state, with $66.7 \%$ at $<37$ weeks of the gestation period (121). Similar to Turkey, maternal mortalities have not been associated with SARS-CoV-2 infection in China $(117,122,123)$. However, deaths have been reported from developing as well as developed nations $(124,125)$.

Although, under-reporting of maternal deaths due to COVID19-related complications is highly likely, another issue while elucidating SARS-CoV-2 infected pregnancies is the lack of true denominator value. A possible solution may be to include the entire pregnancies in investigations, but the use of sophisticated and expensive techniques, like real-time RTPCR for confirmatory diagnosis of SARS-CoV-2 infection, poses limitations. Reliable serological assays become when available may aid in resolving this constraint. Assessment of seroconversion rates in stratified unselected samples can be another approach (given the fact that blood specimens are commonly collected from pregnant women for routine antenatal investigations). Nevertheless, at present, robust estimates of COVID-19 severity and risk of morbidity and mortality in pregnant women are needed. For this, large-scale analysis from different geographical regions is required. Converging data from different countries would be necessary to neutralize the effects of confounding factors and outcome modifiers. Simulation/ prediction models are only assumptions and hence, accurate clinical data with rigorous collection protocols, although more nuanced, would enable the generation of real scenarios. Although analysis and conclusions made out of small-scale uncontrolled studies need to be done cautiously, the risk of COVID-19 in pregnancy cannot be avoided.

\section{Risk to the Developing Fetus}

One of the major concerns of the medical fraternity during COVID-19 has been the vertical transmission of the SARS-CoV2 infection and the adverse fetal outcomes. Although, there have been no reported cases of vertical transmission from SARS-/ MERS-CoV infections, the fear existed in the case of SARS-CoV2. The SARS-CoV-2 gains entry into the host cell by binding to the angiotensin-converting enzyme 2 (ACE2) receptor, which is present in the placenta (126) and also expressed in syncytiotrophoblast, cytotrophoblast, endothelium, and vascular smooth muscle cells from both primary and secondary villi (127). Furthermore, there have been reports suggesting the presence of ACE2 in female reproductive organs, viz., ovary, uterus, and vagina (128). In a nutshell, the ACE2 receptor is expressed in a variety of tissues involved throughout a pregnancy period. A recent single-cell RNA sequencing investigation demonstrated ACE2 expression in the cells (stromal, perivascular, placental, and decidual) at the maternal-fetal interface (129). Another similar investigation by single-cell RNA sequencing highlighted the limited co-expression of ACE2 with the TMPRSS2 in placental cells throughout the pregnancy period, however, suggested viral entry into placenta cells via ACE2 and a non-canonical cell-entry mediator (130).

The adverse fetal outcomes include preterm labor and delivery, premature rupture of membranes, low birth weight, intrauterine fetal distress and growth restraint, feeding intolerance, asphyxia, pneumonia, and respiratory distress. 
Such observations require further confirmatory studies, though. In one such case, a COVID-19 confirmed mother with severe complications, i.e., pneumonia with mechanical ventilation support, ECMO (extracorporeal membrane oxygenation), and MODS delivered a stillborne infant who was negative for SARS-CoV-2 infection (37).

With regard to vertical transmission, different studies involving patients in China, indicated an overall 2\% (8/397) incidence of mother to fetus transmission of the virus (1). Yan and colleagues investigated 116 SARS-CoV-2 infected pregnant women (forming one of the largest cohorts) in China. Of the 100 neonates, 86 were sampled for nasopharyngeal swab (NPS) testing, and none of them were positive for the SARS-CoV2 virus (117). Another large cohort study conducted in the United Kingdom investigated 427 pregnant COVID-19 patients. Of the 244 neonates sampled for NPS, 12 were positive for the SARS-CoV-2, indicating a $4.9 \%$ rate of vertical transmission (118). In another analysis done in a hospital located in New York, it was found that none of the 48 newborns, who were tested on the same day of birth, were positive for SARS-CoV-2 (131). In Italy, 3 out of 42 newborns, within $48 \mathrm{~h}$ of birth, exhibited positive SARS-CoV-2 NPS tests (132). As per the current data, a 3.5\% (19/539) incidence of SARS-CoV-2 vertical transmission can be recorded (1) for the neonates tested outside China. As per a meta-analysis, of 38 cohort/case studies, performed by Kotlyar and the research group, an overall $3.2 \%$ pooled proportion tested positive for viral RNA in NPS of newborns sampled right after or within $48 \mathrm{~h}$ of birth (1). In another analysis, a rate of 3.91\% was indicated for vertical transmission of the SARS-CoV-2 based on viral RNA positivity (119). In an interesting study on a neonate born to a COVID-19 confirmed mother, anti-SARSCoV-2 IgG and IgM antibodies were detected $2 \mathrm{~h}$ after delivery. Also, the infant showed elevated levels of cytokines, however, the viral RNA could not be detected in NPS, placenta, umbilical cord blood, amniotic fluid, maternal blood, vaginal secretions, or even breastmilk (133). Few initial investigations done in China demonstrated the presence of anti-SARS-CoV-2 IgM antibodies in neonates born to COVID-19 confirmed mothers $(134,135)$, suggesting in utero viral transfer of IgM cannot pass through the placenta.

\section{CHANGES IN MATERNAL IMMUNE SYSTEM DURING PREGNANCY}

The onset of pregnancy imposes considerable challenges to maternal health. Right from the beginning, the pregnant female encounters risk from as close as the paternal alloantigens (expressed by both fetus and placenta). Fortunately, mother nature has taken care of the mothers-to-be, and, thus, a classic response to the paternal alloantigens is not observed in general (136); the alloantigens may retain maternal blood and tissue for a prolonged duration even after childbirth (137).

During pregnancy, circulation of monocytes, granulocytes, pDCs, and mDCs increases in blood with peaks occurring in two trimesters, with a parallel decrease in $\mathrm{CD} 3, \mathrm{CD} 4$, and $\mathrm{CD} 8 \mathrm{~T}$ cells, as compared to the post-partum period. While the number of B cells declines in the third trimester, NK cells CD56 decline in the last two trimesters of pregnancy. The latter is also the time when levels of IFN- $\gamma$, TNF, and IL- 6 decline in contrast to the post-partum period (138); however, these observations are contradictory (139). The number of maternal monocytes remains unaffected; instead, phenotypic alterations have been noted, such as elevated expression of CD11a, CD11b, CD54, and CD64 (139). By the 13th week of gestation, the maternal PBMCs begin to harbor phenotypic and functional modifications. Elevated secretion of IL-1 $\beta$ and IL-12 with a simultaneous decline in TNF- $\alpha$ is observed (140).

\section{Maternal-Fetal Interface}

The maternal-fetal interface is essentially formed by the placenta, which develops from the uterine wall and is capable to express various receptors and micro-vesicles (141). The placenta connects and provides hormonal, nutritional, and oxygen supply to the developing fetus while also moderating the mother's immune responses (142). Decidual cells, uterine NK cells, DCs, and Tregs form at the maternal side of the placenta, while the placental villus (fetal blood vessels along with fibroblasts) and placental villous macrophages are of fetal origin, and Hofbauer cells constitute the fetal side of the placenta (61, 143). The number of regulatory $\mathrm{T}$ cells (Tregs) increases in pregnancy, specifically in peripheral, deciduous, and umbilical cord blood (144). Such elevated numbers are important as the Tregs stimulate expression of IL-10 and TGF- $\beta$, which, in turn, modulates $\mathrm{CD} 4+\mathrm{T}$ and $\mathrm{CD} 8+\mathrm{T}$ lymphocyte levels during pregnancy (145).

Furthermore, in the early pregnancy period, NK cells (contributing to about $70 \%$ of decicuous leukocytes) are accumulated at the maternal-fetal interface in early pregnancy (146). Such an interesting feature is important since the NK cells modulate the release of cytokines and chemokines, control the invasion of trophoblasts, and warrant a sufficient supply of maternal blood $(143,146,147)$. Also, changes in the hormone levels regulate maternal immune responses during pregnancy, for instance, the number of DCs and monocytes reduces, activation of macrophages, T, and B cells also declines (148). Estrogen reportedly stimulates Foxp3 Tregs in order to efficiently establish a tolerogenic milieu (149).

\section{IMMUNOLOGICAL ACCOUNT OF SARS-COV-2 INFECTION DURING PREGNANCY}

Serological investigations have indicated incidence of lymphopenia, neutrophilia, elevated CRP (C-reactive protein) $(133,150)$, ALT, AST, and D-dimer upon SARS-CoV-2 infection during pregnancy $(133,135,151)$. In a study, few COVID-19 positive cases developed anemia and dyspnea (152). Another report highlighted the potential effects of altered calcium and albumin levels in the severity of SARS-CoV-2 infection during pregnancy $(153,154)$. Low platelet count has been linked to COVID-19 related deaths in pregnancy $(155,156)$. In spite of the indications from few cases, conclusive statements cannot be 
made on the effects exerted by SARS-CoV-2 on maternal and fetal health due to limited evidence. Long-term effects of stress and physiological temperature control in COVID-19 confirmed pregnancies are speculated. Elevated IL-10 levels in COVID-19 confirmed mothers may modulate inflammation and sustain pregnancy $(64,157)$.

A noteworthy observation following the 2009 influenza pandemic was a decline in cytokine response to bacterial infections. This is finding is crucial as it indicates that SARS$\mathrm{CoV}-2$ infection may also cause impaired immune responses to any other future infections or even insufficient immunological responses to vaccines.

\section{CONCLUSION}

Although, the role of virus infections in increasing morbidity and mortality during pregnancy is well-perceived, yet limited information is available on the mechanism of pregnancyled maternal responses to viral invasion. The emergence of the current pandemic virus strain, i.e., SARS-CoV-2, has spanned a year; little is known about its pathogenesis, clinical signs, and symptoms, disease course, and the adverse outcomes it may have on maternal/fetal health. Furthermore, harboring of different mutations as per the geographical

\section{REFERENCES}

1. Kotlyar A, Grechukhina O, Chen A, Popkhadze S, Grimshaw A, Tal O, et al. Vertical transmission of coronavirus disease 2019: a systematic review and meta-analysis. Am J Obstet Gynecol. (2020) 31:S0002-9378(20)30823-1. doi: 10.1016/j.ajog.2020.07.049

2. Newell M. Vertical transmission of hIV-1 infection. Trans $R$ Soc Trop Med Hyg. (2000) 94:1-2. doi: 10.1016/S0035-9203(00)90413-9

3. Gumbo F, Duri K, Kandawasvika G, Kurewa N, Mapingure M, Munjoma M, et al. Risk factors of hIV vertical transmission in a cohort of women under a pMTCT program at three peri-urban clinics in a resource-poor setting. $J$ Perinatol. (2010) 30:717-23. doi: 10.1038/jp.2010.31

4. Bebell L, Oduyebo T, Riley L. Ebola virus disease and pregnancy: a review of the current knowledge of ebola virus pathogenesis, maternal, neonatal outcomes. Birth Defects Res. (2017) 109:353-62. doi: 10.1002/bdra. 23558

5. Alvarado M, Schwartz D. Zika virus infection in pregnancy, microcephaly, and maternal and fetal health: what we think, what we know, and what we think we know. Arch Pathol Lab Med. (2017) 141:26-32. doi: 10.5858/arpa.2016-0382-RA

6. Schwartz D. The origins and emergence of zika virus, the newest tORCH infection: what's old is new again. Arch Pathol Lab Med. (2017) 141:18-25. doi: 10.5858/arpa.2016-0429-ED

7. WHO. Influenza update-383. (2020). Available on: https://www.who. int/influenza/surveillance_monitoring/updates/latest_update_GIP_ surveillance/en/ (accessed December 30, 2020).

8. Dochez A, Mills K, Kneeland Y. Studies of the etiology of influenza. Proc Soc Exp Biol Med. (1934-1935) 30:1017-22. doi: 10.3181/00379727-30-6776

9. Taubenberger J, Hultin J, Morens D. Discovery and characterization of the 1918 pandemic influenza virus in historical context. Antivir Ther. (2007) 12 (4 Pt B):581-91.

10. CDC Cytomegalovirus. (2020). Available online at: https://www.cdc.gov/ cmv/overview.html\#: :text=People\%20with\%20CMV\%20may\%20pass, Through\%20sexual\%20contact (accessed December 30, 2020). Last updated on: August 18, 2020.

11. Al Mana H, Yassine H, Younes N, Al-Mohannadi A, Al-Sadeq D, Alhababi D, et al. The current status of cytomegalovirus (CMV) prevalence regions (158) suggests the adaptation of the SARS-CoV-2 and its continued circulation among humans. Dedicated studies involving appropriate methodology, controls, effective sample size, and assessment of various parameters need to be performed to ascertain the exact effects of the SARS-CoV-2 infection during different trimesters of pregnancy, effects of cytokine storm to neonatal well-being, and other potential implications. This would be essential in defining guidelines for mandatory testing and post-diagnosis perinatal care.

\section{AUTHOR CONTRIBUTIONS}

RR conceived, conceptualized, searched, analyzed the information/data, drafted the initial manuscript, and reviewed the final version. JS provided considerable intellectual input, analyzed the data, and reviewed the final version of the manuscript. All authors contributed to the article and approved the submitted version.

\section{FUNDING}

JS received institutional support while preparation of the manuscript.

in the mENA region: a Systematic review. Pathogens. (2019) 8:213. doi: $10.3390 /$ pathogens 8040213

12. Ho M. The history of cytomegalovirus and its diseases. Med Microbiol Immunol. (2008) 197:65-73. doi: 10.1007/s00430-007-0066-x

13. Leruez-Ville M, Foulon I, Pass R, Ville Y. Cytomegalovirus infection during pregnancy: state of the science. Am J Obstet Gynecol. (2020) 223:330-49. doi: 10.1016/j.ajog.2020.02.018

14. Brown Z, Wald A, Morrow R, Selke S, Zeh J, Corey L. Effect of serologic status and cesarean delivery on transmission rates of herpes simplex virus from mother to infant. JAMA. (2003) 2003:203-209. doi: 10.1001/jama.289.2.203

15. Brown Z, Benedetti J, Selke S, Ashley R, Watts D, Corey L. Asymptomatic maternal shedding of herpes simplex virus at the onset of labor: relationship to preterm labor. Obstet Gynecol. (1996) 87:483-8. doi: 10.1016/0029-7844(95)00457-2

16. Brown ZAG, Wald A, Morrow R, Corey L. Genital herpes complicating pregnancy. Obstet Gynecol. (2005) 2005:845-56. doi: 10.1097/01.AOG.0000180779.35572.3a

17. Enright AMP. Neonatal herpes infection: diagnosis, treatment and prevention. Semin Neonatol. (2002) 7:283-91. doi: 10.1053/siny.2002.0115

18. White JG. Fulminating infection with herpes-simplex virus in premature and newborn infants. N Engl J Med. (1963) 269:455-60. doi: 10.1056/NEJM196308292690906

19. Tillieux S, Halsey W, Thomas E, Voycik J, Sathe G, Vassilev V. Complete dNA sequences of two oka strain varicella-zoster virus genomes. J Virol. (2008) 82:11023-44. doi: 10.1128/JVI.00777-08

20. Ligon B. Thomas huckle weller $\mathrm{mD}$ : nobel laureate and research pioneer in poliomyelitis, varicella-zoster virus, cytomegalovirus, rubella, and other infectious diseases. Semin Pediatr Infect Dis. (2002) 13:55-63. doi: 10.1053/spid.2002.31314

21. Chernyshov V, Slukvin I, Bondarenko G. Phenotypic characterization of $\mathrm{cD} 7+, \mathrm{CD} 3+$, and $\mathrm{cD} 8+$ lymphocytes from first trimester human decidua using two color flow cytometry. Am J Reprod Immunol. (1993) 29:5-16. doi: 10.1111/j.1600-0897.1993.tb00831.x

22. Polaris Observatory HCV Collaborators. Global prevalence and genotype distribution of hepatitis C virus infection in 2015: a modelling study. Lancet Gastroenterol Hepatol. (2017) 2:161-76. doi: 10.1016/S2468-1253(16)30181-9 
23. Mohd Hanafiah K, Groeger J, Flaxman A, Wiersma S. Global epidemiology of hepatitis c virus infection: new estimates of age-specific antibody to hCV seroprevalence. Hepatology. (2013) 57:1333-342. doi: 10.1002/hep.26141

24. Kumar A, Beniwal M, Kar P, Sharma J, Murthy N. Hepatitis e in pregnancy. Int J Gynaecol Obstet. (2004) 85:240-4. doi: 10.1016/j.ijgo.2003.11.018

25. German Advisory Committee Blood. Subgroup 'Assessment of Pathogens Transmissible by Blood'. Human Immunodeficiency Virus (HIV). Transfus Med Hemother. (2016) 43:203-22. doi: 10.1159/000445852

26. Avert. GlobalHIV AIDS Statistics. (2020). Available online at: https://www. avert.org/global-hiv-and-aids-statistics. Last updated: 18 February (2020) (accessed December 30, 2020).

27. Monebenimp F, Nga-Essono D. Zoung-Kany Bissek A, Chelo D, Tetanye E. HIV exposure and related newborn morbidity and mortality in the university teaching hospital of yaoundé, cameroon. Pan Afr Med J. (2011) 8:43. doi: 10.4314/pamj.v8i1.71160

28. Barré-Sinoussi F, Chermann J, Rey F, Nugeyre M, Chamaret S, Gruest J, et al. Isolation of a t-lymphotropic retrovirus from a patient at risk for acquired immune deficiency syndrome (AIDS). Science. (1983) 220:868-871. doi: $10.1126 /$ science.6189183

29. Schmid S. The discovery of hIV-1. Nature Communications Milestones. (2018). Availablr online at: https://www.nature.com/articles/d42859-018-00003-x

30. Hills S, Fischer M, Petersen L. Epidemiology of zika virus infection. J Infect Dis. (2017) 216:S868-S74. doi: 10.1093/infdis/jix434

31. Melo A, Aguiar R, Amorim M, Arruda M, Melo F, Ribeiro S, et al. Congenital zika virus infection: beyond neonatal microcephaly. JAMA Neurol. (2016) 73:1407-16. doi: 10.1001/jamaneurol.2016.3720

32. Ades A, Soriano-Arandes A, Alarcon A, Bonfante F, Thorne C, Peckham C, et al. Vertical transmission of zika virus and its outcomes: a bayesian synthesis of prospective studies. Lancet Infect Dis. (2021) 21:537-45. doi: 10.1016/S1473-3099(20)30432-1

33. Malvy D, McElroy A, de Clerck H, Günther S, van Griensven J. Ebola virus disease. Lancet. (2019) 393:936-48. doi: 10.1016/S0140-6736(18)33132-5

34. Coronaviridae Study Group of the International Committee on Taxonomy of Viruses. The species Severe acute respiratory syndrome-related coronavirus: classifying 2019-nCoV and naming it SARS-CoV-2. Nat Microbiol. (2020) 5:536-44. doi: 10.1038/s41564-020-0695-Z

35. Zhu N, Zhang D, Wang W, Li X, Yang B, Song J, et al. A novel coronavirus from patients with pneumonia in China, (2019). N Engl J Med. (2020) 382:727-33. doi: 10.1056/NEJMoa2001017

36. Mor G, Aldo P, Alvero A. The unique immunological and microbial aspects of pregnancy. Nat Rev Immunol. (2017) 17:469-82. doi: 10.1038/nri.2017.64

37. Liu H, Wang L, Zhao S, Kwak-Kim J, Mor G, Liao A. Why are pregnant women susceptible to COVID-19? An immunological viewpoint. J Reprod Immunol. (2020) 139:103122. doi: 10.1016/j.jri.2020.103122

38. Price M, Fisher-Hoch S, Craven R, McCormick J. A prospective study of maternal and fetal outcome in acute lassa fever infection during pregnancy. BMJ. (1988) 297:584-7. doi: 10.1136/bmj.297.6648.584

39. Jamieson D, Uyeki T, Callaghan W, Meaney-Delman D, Rasmussen S. What obstetrician-Gynecologists should know about ebola: a Perspective from the centers for disease control and prevention. Obstet Gynecol. (2014) 124:100510. doi: 10.1097/AOG.0000000000000533

40. Kourtis A, Read J, Jamieson D. Pregnancy and infection. N Engl J Med. (2014) 370:2211-8. doi: 10.1056/NEJMra1213566

41. Kwon J, Romero R, Mor G. New insights into the relationship between viral infection and pregnancy complications. Am J Reprod Immunol. (2014) 71:387-90. doi: 10.1111/aji.12243

42. CDC. Centers for Disease Control and Prevention. Types of Influenza Viruses. (2020). Available online at: https://www.cdc.gov/flu/about/ viruses/types.htm\#: :text=There\%20are\%20four\%20types\%20of,global \%20epidemics\%20of\%20flu\%20disease. Updated on November 18, (2019) (accessed December 23, 2020).

43. Uyeki T, Bernstein H, Bradley J, Englund J, File T, Fry A, et al. Clinical practice guidelines by the infectious diseases society of america: 2018 Update on diagnosis, treatment, chemoprophylaxis, and institutional outbreak management of seasonal influenza Clin Infect Dis. (2019) 68:e1-e47. doi: $10.1093 /$ cid/ciy866

44. JW, H. Influenza occurring in pregnant women. JAMA. (1919) 72:978-80. doi: 10.1001/jama.1919.02610140008002
45. Freeman DWB. Deaths from asian influenza associated with pregnancy. Am J Obstet Gynecol. (1959) 78:1172-7. doi: 10.1016/0002-9378(59)90570-8

46. Nuzum JWP, Stangl F, Bonar B. Pandemic influenza and pneumonia in a large civilian hospital. JAMA. (1918) 71:1562-7. doi: 10.1001/jama.1918.26020450009011a

47. Wilson MGS. Teratogenic effects of asian influenza. An extended study. JAMA. (1969) 210:336-44. doi: 10.1001/jama.1969.03160280076019

48. Hardy JMA, Mannini A, Medearis D Jr, Cooke R. The effect of asian influenza on the outcome of pregnancy, baltimore, 1957-1958. Am J Public Health. (1961) 51:1182-90. doi: 10.2105/AJPH.51.8.1182

49. Neuzil KMR, Mitchel E, Simonsen L, Griffin M. Impact of influenza on acute cardiopulmonary hospitalizations in pregnant women. Am J Epidemiol. (1998) 148:1094-102. doi: 10.1093/oxfordjournals.aje.a009587

50. Mullooly JPB, Nolan T Jr. Risk of acute respiratory disease among pregnant women during influenza A epidemics. Public Health Rep. (1986) 101:205-16.

51. Cox SP, McPheeters M, Jamieson D, Kourtis A, Meikle S. Hospitalizations with respiratory illness among pregnant women during influenza season. Obstet Gynecol. (2006) 107:1315-22. doi: 10.1097/01.AOG.0000218702.92005.bb

52. Tse H, To K, Wen X, Chen H, Chan K, Tsoi H, et al. Clinical and virological factors associated with viremia in pandemic influenza a/H1N1/2009 virus infection. PLoS ONE. (2011) 6:e22534. doi: 10.1371/journal.pone.0022534

53. Irving W, James D, Stephenson T, Laing P, Jameson C, Oxford J, et al. Influenza virus infection in the second and third trimesters of pregnancy: a clinical and seroepidemiological study. BJOG. (2000) 107:1282-1291. doi: 10.1111/j.1471-0528.2000.tb11621.x

54. Fatemi S, Earle J, Kanodia R, Kist D, Emamian E, Patterson P, et al. Prenatal viral infection leads to pyramidal cell atrophy and macrocephaly in adulthood: implications for genesis of autism and schizophrenia. Cell $\mathrm{Mol}$ Neurobiol. (2002) 22:25-33. doi: 10.1023/A:1015337611258

55. Shi LF, Sidwell R, Patterson P. Maternal influenza infection causes marked behavioral and pharmacological changes in the offspring. J Neurosci. (2003) 23:297-302. doi: 10.1523/JNEUROSCI.23-01-00297.2003

56. Kwan MLM, Crouse V, Buffler P. Maternal illness and drug/medication use during the period surrounding pregnancy and risk of childhood leukemia among offspring. Am J Epidemiol. (2007) 165:27-35. doi: 10.1093/aje/kwj336

57. Ebert TK. Prenatal exposure to influenza and the risk of subsequent development of schizophrenia. Isr Med Assoc J. (2005) 7:35-43.

58. Takahashi MY. A possible role of influenza a virus infection for parkinson's disease. Adv Neurol. (2001) 86:91-104.

59. Syggelou A, Iacovidou N, Kloudas S, Christoni Z, Papaevangelou V. Congenital cytomegalovirus infection. Ann N Y Acad Sci. (2010) 1205:144-7. doi: 10.1111/j.1749-6632.2010.05649.x

60. Murray M, Bonilla-Medrano N, Lee Q, Oxenford S, Angell R, Depledge $\mathrm{D}$, et al. Evasion of a human cytomegalovirus entry inhibitor with potent cysteine reactivity is concomitant with the utilization of a heparan sulfate proteoglycan-Independent route of entry. J Virol. (2020) 94:e02012-19. doi: 10.1128/JVI.02012-19

61. Racicot K, Mor G. Risks associated with viral infections during pregnancy. J Clin Invest. (2017) 127:1591-9. doi: 10.1172/JCI87490

62. Kenneson A, Cannon M. Review and meta-analysis of the epidemiology of congenital cytomegalovirus (CMV) infection. Rev Med Virol. (2007) 17:253-76. doi: 10.1002/rmv.535

63. McCarthy M, Auger D, Whittemore S. Human cytomegalovirus causes productive infection and neuronal injury in differentiating fetal human central nervous system neuroepithelial precursor cells. J Hum Virol. (2000) 3:215-28.

64. Erydin I, Dik B. Effect of anti-TNF-a on the development of offspring and pregnancy loss during pregnancy in rats. Acta Sci Vet. (2016) 44:1350.

65. Picone O, Vauloup-Fellous C, Cordier A, Guitton S, Senat M, Fuchs F, et al. A series of 238 cytomegalovirus primary infections during pregnancy: description and outcome. Prenat Diagn. (2013) 33:751-8. doi: $10.1002 / \mathrm{pd} .4118$

66. Tassin M, Martinovic J, Mirand A, Peigue-Lafeuille H, Picone O, Benachi A, et al. A case of congenital echovirus 11 infection acquired early in pregnancy. J Clin Virol. (2014) 59:71-3. doi: 10.1016/j.jcv.2013.11.003

67. Fowler K, McCollister F, Dahle A, Boppana S, Britt W, Pass R. Progressive and fluctuating sensorineural hearing loss in children with 
asymptomatic congenital cytomegalovirus infection. J Pediat. (1997) 130:624-30. doi: 10.1016/S0022-3476(97)70248-8

68. Xu F, Lee FK, Morrow RA, Sternberg MR, Luther KE, Dubin G, et al. Seroprevalence of herpes simplex virus type 1 in children in the United States. J Pediatr. (2007) 151:374-77.

69. Gottlieb S, Douglas J, Schmid D, Bolan G, Iatesta M, Malotte C, et al. Seroprevalence and correlates of herpes simplex virus type 2 infection in five sexually transmitted-disease clinics. J Infect Dis. (2002) 186:1381-9. doi: $10.1086 / 344317$

70. Brown Z, Selke S, Zeh J, Kopelman J, Maslow A, Ashley R, et al. The acquisition of herpes simplex virus during pregnancy. N Engl J Med. (1997) 337:509-15. doi: 10.1056/NEJM199708213370801

71. Xu F, Sternberg M, Kottiri B, McQuillan G, Lee F, Nahmias A, et al. Trends in herpes simplex virus type 1 and type 2 seroprevalence in the united states. JAMA. (2006) 296:964-73. doi: 10.1001/jama.296.8.964

72. O'Boyle MKPD. Fetal infections. In: ND et al., editor. Diagnostic Imaging of Fetal Anomalies. Philadelphia: Lippincott Williams \& Wilkins (2003).p. 745-76.

73. Pastuszak A, Levy M, Schick B, Zuber C, Feldkamp M, Gladstone J, et al. Outcome after maternal varicella infection in the first 20 weeks of pregnancy. N Engl J Med. (1994) 330:1305. doi: 10.1056/NEJM199403313301305

74. ACOG. ACOG Practice erinatal Viral and Parasitic Infections. Number 20, September (2000). (Replaces educational bulletin number 177, February 1993). American College of Obstetrics and Gynecologists. Int J Gynaecol Obstet. (2000) 76:95-107.

75. Lamont R, Sobel J, Carrington D, Mazaki-Tovi S, Kusanovic J, Vaisbuch E, et al. Varicella-zoster virus (chickenpox) infection in pregnancy. Bjog. (2011) 118:1155-62. doi: 10.1111/j.1471-0528.2011. 02983.x

76. Huang Q, Huang Q, Zhong M,Wei S S, Luo,, Li F, et al. Chronic hepatitis c virus infection is associated with increased risk of preterm birth: a meta-analysis of observational studies. J Viral Hepat. (2015) 22:1033-42. doi: $10.1111 /$ jvh. 12430

77. Stokkeland K, Ludvigsson J, Hultcrantz R, Ekbom A, Hoijer J, Bottai M, et al. Pregnancy outcome in more than 5000 births to women with viral hepatitis: a population-based cohort study in sweden. Eur J Epidemiol. (2017) 32:617-25. doi: 10.1007/s10654-017-0261-z

78. Marschall H, Wikstrom Shemer E, Ludvigsson J, Stephansson O. Intrahepatic cholestasis of pregnancy and associated hepatobiliary disease: a populationbased cohort study. Hepatology. (2013) 58:1385-91. doi: 10.1002/hep.26444

79. Kushner T, Reau N. Changing epidemiology, implications, and recommendations for hepatitis $\mathrm{c}$ in women of childbearing age and during pregnancy. J Hepatol. (2020) 74:734-41. doi: 10.1016/j.jhep.2020.11.027

80. Rossi R, Wolfe C, Brokamp R, McAllister J, Wexelblatt S, Warshak C, et al. Reported prevalence of maternal hepatitis $c$ virus infection in the united states. Obstet Gynecol. (2020) 135:387-95. doi: 10.1097/AOG.0000000000003644

81. Hofstraat SH, Falla A, Duffell E, Hahne SJ, Amato-Gauci A, Veldhuijzen $\mathrm{I}$, et al. Current prevalence of chronic hepatitis $\mathrm{b}$ and $\mathrm{c}$ virus infection in the general population, blood donors and pregnant women in the eU/EEA: a systematic review. Epidemiol Infect. (2017) 145:2873-85. doi: 10.1017/S0950268817001947

82. Bigna J, Kenne A, Hamroun A, Ndangang M, Foka A, Tounouga D, et al. Gender development and hepatitis $\mathrm{b}$ and $\mathrm{c}$ infections among pregnant women in africa: a systematic review and meta-analysis. Infect Dis Poverty. (2019) 8:16. doi: 10.1186/s40249-019-0526-8

83. Benova L, Mohamoud Y, Calvert C, Abu-Raddad L. Vertical transmission of hepatitis c virus: systematic review and meta-analysis. Clin Infect Dis. (2014) 59:765-73. doi: 10.1093/cid/ciu447

84. Gowda C, Smith S, Crim L, Moyer K, Sanchez P, Honegger J. Nucleic acid testing for diagnosis of perinatally-acquired hepatitis $\mathrm{c}$ virus infection in early infancy. Clin Infect Dis. (2020). doi: 10.1093/cid/ciaa949. [Epub ahead of print].

85. Dominguez-Rodriguez S, Prieto L, Fernandez McPhee C, Illan-Ramos M, Beceiro J, Escosa L, et al. Perinatal hCV transmission rate in hIV/HCV coinfected women with access to aRT in madrid, spain. PLoS ONE. (2020) 15:e0230109. doi: 10.1371/journal.pone.0230109
86. Cottrell E, Chou R, Wasson N, Rahman B, Guise J. Reducing risk for mother-to-infant transmission of hepatitis $\mathrm{c}$ virus: a systematic review for the u.S. Preventive Services Task Force. Ann Intern Med. (2013) 158:109-13. doi: 10.7326/0003-4819-158-2-201301150-00575

87. Nayak N, Panda S, Datta R, Zuckerman A, Guha D, Madanagopalan N, et al. Aetiology and outcome of acute viral hepatitis in pregnancy. J Gastroenterol Hepatol. (1989) 4:345-52. doi: 10.1111/j.1440-1746.1989.tb00846.x

88. Khuroo M, Teli M, Skidmore S, Sofi M, Khuroo M. Incidence and severity of viral hepatitis in pregnancy. Am J Med. (1981) 70:252-5. doi: 10.1016/0002-9343(81)90758-0

89. Jaiswal S, Jain A, Naik G, Soni N, Chitnis D. Viral hepatitis during pregnancy. Int J Gynaecol Obstet Off Organ Int Fed Gynaecol Obstet. (2001) 72:103-8. doi: 10.1016/S0020-7292(00)00264-2

90. Patra S, Kumar A, Trivedi S, Puri M, Sarin S. Maternal and fetal outcomes in pregnant women with acute hepatitis e virus infection. Ann Intern Med. (2007) 147:28. doi: 10.7326/0003-4819-147-1-200707030-00005

91. Karna R, Hazam R, Borkakoti J, Kumar A, Kar P. A 5-year single-Center experience of hepatitis e Virus infection during pregnancy. J Clin Exp Hepatol. (2020) 10:135-8. doi: 10.1016/j.jceh.2019.09.003

92. Perez-Gracia M, Suay-Garcia B, Mateos-Lindemann M. Hepatitis e. and pregnancy: current state. Rev Med Virol. (2017) 27:e1929. doi: $10.1002 / \mathrm{rmv} .1929$

93. Khuroo M, Khuroo M, Khuroo N. Hepatitis e: discovery, global impact, control and cure. World J Gastroenterol. (2016) 22:7030-45. doi: 10.3748/wjg.v22.i31.7030

94. Khuroo MS, Kamili S, Khuroo MS. Clinical course and duration of viremia in vertically transmitted hepatitis $\mathrm{E}$ virus (HEV) infection in babies born to HEV-infected mothers. J Viral Hepat. (2009) 16:519-23. doi: 10.1111/j.1365-2893.2009.01101.x

95. Calvet G, Santos F, Sequeira P. Zika virus infection: epidemiology, clinical manifestations and diagnosis. Curr Opin Infect Dis. (2016) 29:459-66. doi: 10.1097/QCO.0000000000000301

96. CDC Lassa Fever. (2019). Available online at: https://www.cdc.gov/vhf/lassa/ index.html\#: :text=The\%20illness\%20was\%20discovered\%20in, therefore \%2C\%20these\%20estimates\%20are\%20crude. Last updated: January 31, (2019) (accessed December 28, 2020).

97. Shrestha P, Bhandari D, Sharma D, Bhandari B. A study of viral hepatitis during pregnancy in nepal medical college teaching hospital. Nepal Med Coll J. (2009) 11:192-4.

98. Khuroo M, Kamili S, Jameel S. Vertical transmission of hepatitis e virus. Lancet. (1995) 345:1025-6. doi: 10.1016/S0140-6736(95)90761-0

99. UNAIDS. Global HIV \& AIDS Statistics 2020 Fact Sheet. Available online at: https://www.unaids.org/en/resources/fact-sheet (accessed December 30, 2020).

100. Harris K., Yudin M H. HIV infection in pregnant women: a (2020). Update. Prenatal Diagnosis. (2020) 40:1715-21. doi: 10.1002/pd.5769

101. Wedi C, Kirtley S, Hopewell S, Corrigan R, Kennedy S, Hemelaar J. Perinatal outcomes associated with maternal hIV infection: a systematic review and meta-analysis. Lancet HIV. (2016) 3:e33-48. doi: 10.1016/S2352-3018(15)00207-6

102. Brabin B. Epidemiology of infection in pregnancy. Rev Infect Dis. (1985) 7:579-603. doi: 10.1093/clinids/7.5.579

103. Racicot K, Aldo P, El-Guindy A, Kwon J, Romero R, Mor G. Cutting edge: fetal/placental type i IFN can affect maternal survival fetal viral load during viral infection. J Immunol. (2017) 198:3029-32. doi: 10.4049/jimmunol.1601824

104. Bello O, Akinajo O, Odubamowo K, Oluwasola T. Lassa fever in pregnancy: report of 2 cases seen at the university college hospital, ibadan. Case Rep Obstet Gynecol. (2016) 2016:9673683. doi: 10.1155/2016/967 3683

105. Kayem N, Benson C, Aye CY, Barker S, Tome M, Kennedy S, et al. Lassa fever in pregnancy: a systematic review and meta-analysis. Trans $R$ Soc Trop Med Hygiene. (2020) 114:385-96. doi: 10.1093/trstmh/traa011

106. Mansuy J, Dutertre M, Mengelle C, Fourcade C, Marchou B, Delobel P, et al. Zika virus: high infectious viral load in semen, a new sexually transmitted pathogen? Lancet Infect Dis. (2016) 16:405. doi: 10.1016/S1473-3099(16)00138-9 
107. Nunes M, Rodrigues L. The epidemic of zika virus-related microcephaly in brazil: detection, control, etiology, future scenarios. Am J Public Health. (2016) 106:601-5. doi: 10.2105/AJPH.2016.303113

108. Calvet G, Aguiar R, Melo AS, Sampaio S, de Filippis I, Fabri A, et al. Detection and sequencing of zika virus from amniotic fluid of fetuses with microcephaly in brazil: a case study. Lancet Infect Dis. (2016) 16:653-60. doi: 10.1016/S1473-3099(16)00095-5

109. Tabata T, Petitt M, Puerta-Guardo H, Michlmayr D, Wang C, Fang-Hoover J, et al. Zika virus targets different primary human placental cells, suggesting two routes for vertical transmission. Cell Host Microbe. (2016) 20:155-66. doi: 10.1016/j.chom.2016.07.002

110. McCormick J, Webb P, Krebs J, Johnson K, Smith E. A prospective study of the epidemiology and ecology of lassa fever. J Infect Dis. (1987) 155:437-44. doi: 10.1093/infdis/155.3.437

111. Kibadi K, Mupapa K, Kuvula K, Massamba M, Ndaberey D, MuyembeTamfum J, et al. Late ophthalmologic manifestations in survivors of the (1995). Ebola virus epidemic in Kikwit, Democratic Republic of the Congo. J Infect Dis. (1999) 179(Suppl 1):S13-S14. doi: 10.1086/514288

112. Guimard Y, Bwaka M, Colebunders R, Calain P, Massamba M, De Roo A, et al. Organization of patient care during the ebola hemorrhagic fever epidemic in kikwit, democratic republic of the congo, (1995). J Infect Dis. (1999) 179(Suppl 1):S268-73. doi: 10.1086/514315

113. Bwaka M, Bonnet M, Calain P, Colebunders R, De Roo A, Guimard Y, et al. Ebola hemorrhagic fever in kikwit, democratic republic of the congo: clinical observations in 103 patients. J Infect Dis. (1999) 179(Suppl 1):S1-S7. doi: $10.1086 / 514308$

114. Mupapa K, Mukundu W, Bwaka M, Kipasa M, De Roo A, Kuvula K, et al. Ebola hemorrhagic fever and pregnancy. J Infect Dis. (1999) 179(Suppl 1):S11-S12. doi: 10.1086/514289

115. Xu Z, Shi L, Wang Y, Zhang J, Huang L, Zhang C, et al. Pathological findings of cOVID-19 associated with acute respiratory distress syndrome. Lancet Respir Med. (2020) 8:420-2. doi: 10.1016/S2213-2600(20) 30076-X

116. Schwartz DA, Graham AL. Potential maternal and infant outcomes from Coronavirus 2019-nCoV (SARS-CoV-2) infecting pregnant women: Lessons from SARS, MERS, and other human coronavirus infections. Viruses. (2020) 12:194. doi: 10.3390/v12020194

117. Yan J, Guo J, Fan C, Juan J, Yu X, Li J, et al. Coronavirus disease 2019 in pregnant women: a report based on 116 cases. Am J Obstet Gynecol. (2020) 223:111.e1-14. doi: 10.1016/j.ajog.2020.04.014

118. Knight M, Bunch K, Vousden N, Morris E, Simpson N, Gale C, et al. Characteristics and outcomes of pregnant women admitted to hospital with confirmed sARS-CoV-2 infection in $\mathrm{uK}$ : national population based cohort study. BMJ. (2020) 369:m2107. doi: 10.1136/bmj.m2107

119. Chi J, Gong W, Gao Q. Clinical characteristics and outcomes of pregnant women with cOVID-19 and the risk of vertical transmission: a systematic review. Arch Gynecol Obstet. (2021) 303:337-45. doi: 10.1007/s00404-020-05889-5

120. Westgren M, Pettersson K, Hagberg H, Acharya G. Severe maternal morbidity and mortality associated with COVID-19: The risk should not be downplayed. Acta Obstet Gynecol Scand. (2020) 99:815-6. doi: 10.1111 /aogs. 13900

121. Tug N, Yassa M, Köle E, Sakin Ö, Çakır Köle M, Karateke A, et al. Pregnancy worsens the morbidity of COVID-19 and this effect becomes more prominent as pregnancy advances. Turk J Obstet Gynecol. (2020) 17:149-54. doi: 10.4274/tjod.galenos.2020.38924

122. Chen L, Li Q, Zheng D, Jiang H, Wei Y, Zou L, et al. Clinical characteristics of pregnant women with covid-19 in Wuhan, China. N Engl J Med. (2020) 382:e100. doi: 10.1056/NEJMc2009226

123. Qiancheng X, Jian S, Lingling P, Lei H, Xiaogan J, Weihua L, et al. Coronavirus disease 2019 in pregnancy. Int J Infect Dis. (2020) 95:376-83. doi: 10.1016/j.ijid.2020.04.065

124. Amorim MM, Takemoto ML, Fonceca E. Maternal deaths with cOVID19: a different outcome from mid to low resource countries? Am J Obstet Gynecol. (2020) 223:298-9. doi: 10.1016/j.ajog.2020.04.023

125. Hantoushzadeh S, Shamshirsaz A, Aleyasin A, Seferovic M, Aski S, Arian S, et al. Maternal death due to cOVID-19 disease. Am J Obstet Gynecol. (2020). doi: 10.1016/j.ajog.2020.04.030
126. Levy A, Yagil Y, Bursztyn M, Barkalifa R, Scharf S, Yagil C. ACE2 expression and activity are enhanced during pregnancy. Am J Physiol Regul Integr Comp Physiol. (2008) 295:R1953-61. doi: 10.1152/ajpregu.90592.2008

127. Valdés G, Neves L, Anton L, Corthorn J, Chacón C, Germain A, et al. Distribution of angiotensin-(1-7) and aCE2 in human placentas of normal and pathological pregnancies. Placenta. (2006) 27:200-7. doi: 10.1016/j.placenta.2005.02.015

128. Jing Y, Run-Qian L, Hao-Ran W, Hao-Ran C, Ya-Bin L, Yang G, et al. Potential influence of cOVID-19/ACE2 on the female reproductive system. Mol Hum Reprod. (2020) 26:367-73. doi: 10.1093/molehr/gaaa030

129. Li M, Chen L, Zhang J, Xiong C, Li X. The sARS-CoV-2 receptor aCE2 expression of maternal-fetal interface and fetal organs by single-cell transcriptome study. PLoS One. (2020) 15:e0230295. doi: 10.1371/journal.pone.0230295

130. Pique-Regi R, Romero R, Tarca A, Luca F, Xu Y, Alazizi A, et al. Does the human placenta express the canonical cell entry mediators for sARS-CoV-2? Elife. (2020) 9:e58716. doi: 10.7554/eLife.58716

131. London V, McLaren, Jr R, Atallah F, Cepeda C, McCalla S, et al. The relationship between status at presentation and outcomes among pregnant women with cOVID-19. Am J Perinatol. (2020) 37:991-4. doi: 10.1055/s-0040-1712164

132. Ferrazzi E, Frigerio L, Savasi V, Vergani P, Prefumo F, Barresi S, et al. Vaginal delivery in sARS-CoV-2-infected pregnant women in northern italy: a retrospective analysis. BJOG. (2020) 127:1116-21. doi: 10.1111/1471-0528.16278

133. Dong L, Tian J, He S, Zhu C, Wang J, Liu C, et al. Possible vertical transmission of sARS-CoV-2 from an infected mother to her newborn. JAMA. (2020) 323:1846-8. doi: 10.1001/jama.2020.4621

134. Lei D, Wang C, Li C, Fang C, Yang W, Cheng B, et al. Clinical characteristics of pregnancy with the 2019 novel coronavirus disease (COVID-19) infection. Chin J Perinat Med. (2020) 23.

135. Zhu H, Wang L, Fang C, Peng S, Zhang L, Chang G, et al. Clinical analysis of 10 neonates born to mothers with 2019-nCoV pneumonia. Transl Pediatr. (2020) 9:51-60. doi: 10.21037/tp.2020.02.06

136. Ando T, Davies F. Self-recognition and the role of fetal microchimerism. Best Pract Res Clin Endocrinol Metab. (2004) 18:197-211. doi: 10.1016/j.beem.2004.03.002

137. Bianchi D, Zickwolf G, Weil G, Sylvester S, DeMaria A. Male fetal progenitor cells persist in maternal blood for as long as 27 years postpartum. Proc Natl Acad Sci USA. (1996) 93:705-8. doi: 10.1073/pnas.93.2.705

138. Luppi P. How immune mechanisms are affected by pregnancy. Vaccine. (2003) 21:3352-7. doi: 10.1016/S0264-410X(03)00331-1

139. Moore A, Brown D, Fairlie W, Bauskin A, Brown P, Munier M, et al. The transforming growth factor-ss superfamily cytokine macrophage inhibitory cytokine- 1 is present in high concentrations in the serum of pregnant women. J Clin Endocrinol Metab. (2000) 85:4781-8. doi: $10.1210 /$ jcem.85.12.7007

140. Luppi P, Haluszczak C, Betters D, Richard C, Trucco M, DeLoia A. Monocytes are progressively activated in the circulation of pregnant women. J Leukoc Biol. (2002) 72:874-84. doi: 10.1034/j.1600-0897.2002.1o041.x

141. Pringle K, Tadros M, Callister R, Lumbers R. The expression and localization of the human placental prorenin/renin-angiotensin system throughout pregnancy: roles in trophoblast invasion and angiogenesis? Placenta. (2011) 32:956-62. doi: 10.1016/j.placenta.2011.09.020

142. Woods L, Perez-Garcia V, Hemberger M. Regulation of placental development and its impact on fetal growth-new insights from mouse models. Front Endocrinol (Lausanne). (2018) 9:570. doi: 10.3389/fendo.2018.00570

143. Ferreira LM, Meissner T, Tilburgs T, Strominger L. HLA-G: at the interface of maternal-fetal tolerance. Trends Immunol. (2017) 38:272-286. doi: 10.1016/j.it.2017.01.009

144. Areia A, Vale-Pereira S, Alves V, Rodrigues-Santos P, Moura P, MotaPinto A. Membrane progesterone receptors in human regulatory $t$ cells: a reality in pregnancy. BJOG. (2015) 122:1544-50. doi: 10.1111/1471-0528. 13294

145. Tsuda S, Nakashima A, Shima T, Saito S. New paradigm in the role of regulatory t cells during pregnancy. Front Immunol. (2019) 10:573. doi: $10.3389 /$ fimmu.2019.00573 
146. Ander S, Diamond M, Coyne B. Immune responses at the maternal-fetal interface. Sci Immunol. (2019) 4:eaat6114. doi: 10.1126/sciimmunol.aat6114

147. Vento-Tormo R, Efremova M, Botting R, Turco M, Vento- Tormo M, Meyer $\mathrm{K}$, et al. Single-cell reconstruction of the early maternal-fetal interface in humans. Nature. (2018) 563:347-353. doi: 10.1038/s41586-018-0698-6

148. Schumacher A, Costa S, Zenclussen C. Endocrine factors modulating immune responses in pregnancy. Front Immunol. (2014) 5:196. doi: $10.3389 /$ fimmu.2014.00196

149. Tai P, Wang J, Jin H, Song X, Yan J, Kang Y, et al. Induction of regulatory t cells by physiological level estrogen. J Cell Physiol. (2008) 214:456-464. doi: 10.1002/jcp.21221

150. Wang S, Guo L, Chen L, Liu W, Cao Y, Zhang J, et al. A case report of neonatal cOVID-19 infection in china. Clin Infect Dis. (2020) 71:853-7. doi: 10.1093/cid/ciaa225

151. Zeng L, Xia S, Yuan W, Yan K, Xiao F, Shao J, et al. Neonatal early-onset infection with sARS-CoV-2 in 33 neonates born to mothers with COVID-19 in wuhan, china. JAMA Pediatr. (2020) 26:e200878. doi: 10.1001/jamapediatrics.2020.0878

152. Chen Y, Peng H, Wang L, Zhao Y, Zeng L, Gao H, et al. Infants born to mothers with a new coronavirus (COVID-19). Front Pediatr. (2020) 8:104. doi: 10.3389/fped.2020.00104

153. Chen S, Liao E, Cao D, Gao Y, Sun G, Shao Y. Clinical analysis of pregnant women with 2019 novel coronavirus pneumonia. J Med Virol. (2020) 92:1-6. doi: 10.1002/jmv.25789

154. El-Kurdi B, Khatua B, Rood C, Snozek C, Cartin-Ceba R, Singh V, et al. Mortality from cOVID-19 increases with unsaturated fat, and may be reduced by early calcium and albumin supplementation. Gastroenterology. (2020) 159:1015-18.e4. doi: 10.1053/j.gastro.2020.05.057
155. Liu Y, Sun W, Guo Y, Chen L, Zhang L, Zhao S, et al. Association between platelet parameters and mortality in coronavirus disease 2019: retrospective cohort study. Platelets. (2020) 31:490-6. doi: 10.1080/09537104.2020.1754383

156. Lippi G, Plebani M, Henry M. Thrombocytopenia is associated with severe coronavirus disease (2019). (COVID-19) infections: a metaanalysis. Clin Chim Acta. (2020) 506:145-8. doi: 10.1016/j.cca.2020. 03.022

157. Thaxton J, Sharma S. Interleukin-10: a multi-faceted agent of pregnancy. Am J Reprod Immunol. (2010) 63:482-91. doi: 10.1111/j.1600-0897.2010. 00810.x

158. Khan M, Khan Z, Baig M, Ahmad I, Farouk A, Song Y, et al. Comparative genome analysis of novel coronavirus (SARS-CoV-2) from different geographical locations and the effect of mutations on major target proteins: an in silico insight. PLoS ONE. (2020) 15:e0238344. doi: 10.1371/journal.pone.0238344

Conflict of Interest: The authors declare that the research was conducted in the absence of any commercial or financial relationships that could be construed as a potential conflict of interest.

Copyright (๑) 2021 Rajput and Sharma. This is an open-access article distributed under the terms of the Creative Commons Attribution License (CC BY). The use, distribution or reproduction in other forums is permitted, provided the original author(s) and the copyright owner(s) are credited and that the original publication in this journal is cited, in accordance with accepted academic practice. No use, distribution or reproduction is permitted which does not comply with these terms. 